\title{
FAKTOR-FAKTOR YANG MEMPENGARUHI LABA USAHA PETERNAKAN AYAM BROILER DI KECAMATAN BANGUN PURBA KABUPATENDELI SERDANG
}

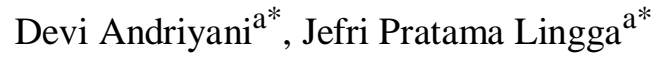 \\ ${ }^{a}$ Fakultas Ekonomi dan Bisnis Universitas Malikussaleh \\ *Corresponding author : jefripratamaekp@gmail.com \\ * devisep80@gmail.com
}

\begin{tabular}{|c|c|}
\hline ARTICLE INFORMATION & A B S T RA C T \\
\hline $\begin{array}{l}\text { Keywords: } \\
\text { Operating Profit, Cage Area, } \\
\text { Seedlings and Feed. }\end{array}$ & $\begin{array}{l}\text { This study aims to determine the effect of factors that affecting the } \\
\text { profitability of broiler farming in the District of Bangun Purba, Deli } \\
\text { Serdang Regency. The study uses stratified random sampling technique } \\
\text { to } 61 \text { respondents. The study uses multiple linear regression method. } \\
\text { The results showed that the wide of the cage (X1) and woof (X3) } \\
\text { negative and significantly affect the profits. The chicks positive and } \\
\text { significantly effect the profits. }\end{array}$ \\
\hline
\end{tabular}

\section{1.}

\section{PENDAHULUAN}

Sektor pertanian adalah sektor paling memegang penting dalam meningkatkan ekonomi Indonesia. satu sub sector pertanian yang memiliki peran yang sangat penting dalam membangun ekonomi Indonesia adalah sub sector peternakan. Peternakan terdiri atas ternak besar seperti ternak sapi perah, sapi potong, kambing, domba, ternak kecil seperti ternak kelinci serta ternak unggas seperti terna kitik, ayam petelur, ayam pedaging, ayam buras, dan burung puyuh(Umam, 2015).

Pembangunan dalam bidang peternakan dapat meningkatkan kehidupan peran peternak dalam tata ekonomi nasional, peningkatan penhasilan peternakan dan menyediakan pangan bagi masyarakat. Salah satunya adalah industri perunggasan di Indonesia diperkirakan memiliki peranan yang pesat. Menurut (Umam, Prayogi, \& Nurgiar tiningsih, 2015), masih terdapat beberapa kendala yang dalam pengembangan perunggasan di Indonesia diantaranya adalah tingginya harga pakan, hal tersebut dikarenakan bahan pakan masih diimpor Namun demikian, industry perunggasan di Indonesia diperkirakan memiliki prospek yang baik karena masih terjadinya pertambahan penduduk, peningkatan pendidikan dan pendapatan, serta kesadaran akan gizi seimbang (Jamaika, 2014)
Salah satu kelompok peternak yang baik untuk dimajukan adalah peternak ayambroiler. Hal tersebut didukung oleh karakteristik produknya yang sangat banyak diminati oleh masyarakat yang memiliki kandungan gizi dan vitamin yang cukup tinggi serta harganya yang sangat rendah jika disamakan dengan daging lainnya. Selain itu, peternak ayam pedaging adalah usaha yang sangat strategis karena kecepatan pertumbuhannya yang relative singkat. Ayamras pedaging mampu menghasilkan daging seberat 1.2-1.9 kg dalam usia 5 hingga 6 minggu (Umam, 2015).

Bangun purba merupakan salah satu kelurahan yang ada di kecamatan Bangun Purba, Kabupaten Deli serdang provinsi Sumatera Utara Potensi utama di kabupaten deli serdanga dalah Pertanian Pangan, Perkebunan Besar, Perkebunan Rakyat, Peternakan, Industri, Perdagangan dan Perikanan Darat. Mata pencarian di Kecamatan Bangun kurba antara lain berkerja sebagai karyawan di perkebunan besar, bekerja sebagai PNS,memiliki perkebunan sendiri, bertenak lembu dan bertenak ayam. Di kecamatan bangun purba memiliki torelansi yang tinggi dan saling menghargai kepercayaan masing-masing

Kepadatan kandang merupakan banyaknya ternak yang dapat tinggal diluas area lantai 
tertentu dengan mempertimbangkan banyaknya ternak dan luas kandang. Kepadatan kandang dipengaruhi oleh jenis, besar kandang nya, dan suhu lingkungan. jenis ayam broiler sekitar 6-7 ekor/m2 luas lantai meter dan 4-5 ekor/m2 untuk ayam jenis dwiguna (tipe medium) (Osborn, 2017).

Dibawah ini adalah hasil wawancara awal dengan beberapa usaha ayam broiler di kecamatan bangun purba kabupaten deli Serdang

\section{Tabel 1}

Hasil wawancara dengan usaha peternak ayam broiler di Kecamatan Bangun Purba Kabupaten Deli Serdang

\begin{tabular}{|c|c|c|c|c|c|}
\hline $\begin{array}{c}\mathbf{N} \\
\mathbf{0}\end{array}$ & Nama & Luas & $\begin{array}{c}\text { Bibitayam } \\
\text { (DOC) }\end{array}$ & PAKAN & Laba \\
\hline 1 & Johanesbarus & $950 \mathrm{~m}^{2}$ & 6650 ekor & $\mathrm{Rp} 119.70$ & $\mathrm{Rp} 46.475$ \\
& & & & 0.000 & .000 \\
\hline 2 & Mahdi siregar & $900 \mathrm{~m}^{2}$ & 6300 ekor & $\mathrm{Rp} 113.40$ & $\mathrm{Rp} 44.800$ \\
& & & & 0.000 & .000 \\
\hline 3 & Nandomanik & $1050 \mathrm{~m}^{2}$ & 6300 ekor & $\mathrm{Rp} 113.40$ & $\mathrm{Rp} 44.800$ \\
& & & & 0.000 & .000 \\
\hline
\end{tabular}

Sumber : Data diolah oktober 2018

Berdasarkan tabel 1 di atas dapat diketahui bahwa johanes baru mengeluarkan biaya yang lebih banyak untuk pakan dari mahdi siregar dan nandomanik. Luas kandang nandomanik lebih luas dari pada johanesbarus, seharusnya nandomanik mendapatkan keuntungan lebih luas dari pada johanesbarus tetapi yang terjadi sebaliknya. Dan luas kendangnan domanik lebih luas dari pada Mahdisiregar akan tetapi mereka memiliki jumlah bibit yang sama, pakan yang sama dan laba. Diketahui bahwa johanesbarus dan Mahdisiregar memiliki kepadatan bibit ayam yang sama

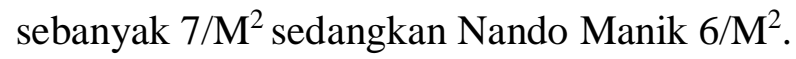

Tujuan dari penelitian ini adalah untuk mengetahui Faktor-faktor yang mempengaruhi Laba usaha Peternakan Ayam Broiler di Kecamatan Purba Kabupaten Deli Serdang”.

Bagian kedua dari penetian ini akan membahas tinjauan teoritis, metode penelitiannya disajikan dibagian ketiga, selanjutnya hasil penelitian serta pembahasan dipaparkan bagian keempat dalam penelitian ini, yang selanjutnya pada bagian akhir merupakan kesimpulan dan saran.

\section{TINJAUAN TEORITIS}

\section{Peternakan Ayam Broiler}

Ayam broiler adalah hasil budidaya teknologi yang memiliki karakteristik ekonomi dengan ciri khas sebagai penghasil daging. Pertumbuhannya cepat dengan konversi makanan yang irit, dan siap dipotong pada usia yang relatif muda, yaitu hanya 5-6 minggu sudah dapat dipanen, dengan berat badan antara 1.2-1.9 $\mathrm{kg}$ /ekor.Ayam broiler yang baik yaitu ayam yang sehat, badan baik, kualitas nya yang baik, dan daging seimbang (proporsional)(Dharmawan, Prayogi, \& Nurgiartiningsih, 2005).

Ayam broiler yang paling banyak di produksi oleh masyarakat adalah jenispedaging (ayam broiler) dan jenis petelur (ayam ras petelur ). Oleh karena itu, di dalam masyarakat ayam broiler hanya dikenal dua jenisyaitu ayam ras pedaging dan jenis yaitu ayam pedaging dan ayampetelur (Dharmawan, Prayogi, \& Nurgiartiningsih, 2005). Hasil dari perkawinan ayam tersebut menghasilkan bibit ayam yang memiliki ungguran pertumbuhan perkembangan badan cepat dan memiliki daya tahan badan.

\section{Pengertian Laba}

Menurut (Umam, 2015)pengertian Laba merupakan kurang pendapatan dari biaya kegiatan usaha. Apabila biaya lebih besar dari pendapatan, selisihnya disebut rugi. Laba atau rugi merupakan hasil perhitungan secara periodik (berkala). Laba atau rugi ini belum merupakan laba atau rugi yang sebenarnya. Laba atau rugi yang sebenarnya baru dapat diketahui apabila perusahaan telah menghentikan kegiatannya dan dilikuidasikan

Menurut (Dharmawan, 2005) pengertian laba (rugi) merupakan pendapatan dikurangi dengan beban atau biaya yang telah dikeluarkan, sebagaimana terlihat dalam persamaan laba (rugi) dibawah ini.

\section{LABA $($ RUGI $)=$ PENDAPATAN - BEBAN/BIAYA}

Berdasarkan hasil pengertian diatas, maka dapat disimpulkan bahwa laba merupakan seluruh total pendapatan yang dikurangi dengan total biaya-biaya 


\section{Bibit ayam (DOC)}

Menurut (Rachmawati, 2017), mengatakan kualitas bibit juga harus menjadi perhatian bagi para peternak sehingga Kontribusi bibit dalam penampilan produksi ternak yang bermutu baik sebesar 30 persen. Bibit yang sangat berkualitas baikdapat diketahui dari catatan produknya dan secara langsung dapat dilihat dari penampilan fisiknya. Bibit DOC yang baik dapat dipilih berdasarkan penampilannya secara umum dari luar (general appearance) adalah sebagai berikut: (1) bebas dari penyakit (free diseases), (2) berasal dari induk yang matang 12 umur dan dari pembibit yang berpengalaman, (3) DOC terlihat aktif, (4) DOC memiliki kekebalan tubuh yang tinggi, (5) kaki besar dan basah seperti berminyak, (6) bulu cerah, tidak kusam, dan penuh, (7) anus bersih, tidak ada kotoran atau pasta putih, (8) keadaan tubuh ayam normal, dan (9) berat badan sesuai standar strain, biasanya diatas 37 gram.

\section{Kandang}

Kandang adalah bagianbangunan yang sangat baik digunakan untuk melindungi ternak mulai dari awal, masa produksi hingga dipasarkan (Dharmawan, 2005). Menurut (Kiki, 2017), dalam usaha peternakan komersial, kandang menjadi salah satu faktor produksi yang harus diperhatikan dengan baik. Kandang padadasarnya berfungsi untuk mempermudahpemeliharaan dan pengontrolan ternak.Kontrobusi kandang harus mendukung kebutuhan pertumbuhan dan perkembangan ternak, antara kebutuhan cahaya, suhu, dan sirkulasi udara tercukupi.

Menurut (Dharmawan, 2005) kandang merupakan tempat hidup dan tempat berproduksi. Djanah menyatakan bahwa kandang yang dibangun harus memenuhi syarat-syarat kesehatan bagi ternak yang akan ditempatkan di dalamnya, yaitu : 1) Letak kandang, kandang hendaknya dibangun lebih tinggi, dipilih tempat yang cukup jauh dari suara gaduh dan aman dari lalu lalang orang atau kendaraan. 2) Ventilasi, merupakan jalan keluar masuknya udara sehingga udara segar dari luar dapat masuk menggantikan udara kotor yang ada dalam kandang. Ventilasi juga berfungsi mengatur kondisi suhu dan kelembaban dalam kandang. 3) Sinar matahari, yang paling baik adalah sinar matahari pagi, sehingga bagian kandang yang terbuka sedapat mungkin menghadap kearah masuknya sinar matahari pagi. 4) Temperatur, temperatur dalam ruangan kandang di daerah tropis sebaiknya 320C untuk awal, selanjutnya temperatur disesuaikan dengan kondisi kandang tersebut. 5) Kelembaban, kelembaban yang tinggi menyebabkan ayam menjadi peka terhadap penyakit-penyakit pernapasan. 6) Pohon pelindung, berfungsi menahan arah angin sehingga kandang tidak begitu banyak mendapat angin secara langsung

Dijelaskan juga oleh (Rachmawati, 2017) konstruksi kandang berdasarkan ukurannya adalah sebagai berikut : 1) Lebar kandang, kandang dengan lebar 6 meter sudah memadai agar sirkulasi udara lancar. Kandang yang jauh dari permukiman lebarnya dapat mencapai 8 meter, 2) Tinggi kandang, bagian terendah atap minimal 2,5 meter untuk mengurangi pancaran panas ke dalam kandang, 3) Panjang kandang, disesuaikan dengan populasi ayam yang akan dipelihara

(Rachmawati, 2017) menyatakan bahwa kandang berperan sangat penting dalam menciptakan kondisi iklim mikro yang diinginkan agar proses- proses fisiologis dapat berjalan sempurna. Peran tersebut diantaranya: 1) menciptakan suasana tetap segar pada musim panas, 2) menciptakan suasana tetap hangat pada keadaan musim dingin, 3) menurunkan kelembapan yang terlalu tinggi, 4) menurunkan kandungan amonia yang terlalu tinggi dan 5) memberikan aliran udara yang baik melalui dinding kendang

Bentuk kandang yang ideal untuk ayam ras pedaging adalah kandang postal. Menurut (Dharmawan, 2005), kandang postal adalah kandang yang berlantai rapat dan biasanya menggunakan alas litter, kandang dapat bertingkat atau tidak dan pada suhu tinggi dindingnya sebagian besar terbuka. Guna mengatasi udara yang panas khususnya di daerah tropis seperti Indonesia, kandang panggung lebih baik untuk digunakan, namun biaya yang dikeluarkan untuk pembuatan kandang panggung lebih mahal.Kandang panggung dibangun dengan 
ketinggian $\pm 1.75 \mathrm{~cm}$, udara datang dari sela-sela lantai dan samping kandang, sehingga udara dalam kandang lebih nyaman, berikut merupakan bagianbagian dari model kendang adalah.

Lokasi kandang harus jauh dari pemukiman penduduk, memiliki sumber air yang cukup terutama pada musim kemarau, bebas dari penghalang sehingga udara bebas keluar masuk, serta lokasi harus memiliki akses jalan, listrik dan telpon(Jamaika et al., 2014)

\section{Pakan}

Pakan merupakan campuran bahan pakan yang mengandung nutrient yang lengkap dan disusun dengan cara tertentu untuk memenuhi kebutuhan zat gizi unggas yang mengkonsumsinya (Rachmawati et al., 2017). Menurut (Rachmawati et al, 2017), pakan merupakan sapronak penting dalam produksi ternak. Diperkirakan biaya pakan dapat mencapai 60-70 persen dari total biaya produksiPengelolaan pakan meliputi jenis pakan, kualitas pakan, waktu pemberian, dan konsentrasi pakan yang diberikan ternak. perlu diperhatikan dalam pemberian pakan harus secara teratur sehingga kebutuhan protein, karbohidrat, lemak, vitamin, dan mineral dapat meningkatkan bobot ayam.Kebutuhan zat merupakan bagi yang sangat penting bagi ternak untuk perkembangan, pertumbuhan, dan kebutuhan aktivitas. Pemberian pakan harus di lakukan secara teratur dengan jumlah yang sesuai kebutuhan ternak. Kelebihan atau kekurangan dalam pemberian pakan akan berdampak kurang baik pada ternak dan berdampak pada efisiensi dalam produksi (Ponaryo, 2017).

Pemberian pakan pada periode starter pada minggu pertama dilakukan secara adil yaitu pemberian pakan secara terus menerus, pemberian pakan ini dilakukan sesering mungkin dengan jumlah sedikit demi sedikit anak ayam pada priode ini masih dalam tahap belajar dan adaptasi dengan lingkungan sehingga pemberian pakan dalam jumlah sedikit dimaksudkan agar tidak banyak terbuang dan tidak tercampur dengan kotoran ayam (Rachmawati et al., 2017).

\section{Pengaruh Luas kandang Terhadap laba usaha peternak ayam broiler}

Luas kandang adalah keseluruhan wilayah yang menjadi tempat peternak, luas kandang menjamin jumlah atau hasil yang di peroleh peternak jika luas kandang meningkat maka pendapatan peternak akan meningkat dan sebaliknya. Jika luas kandang di gunakan sedikit maka pendapatan yang di peroleh peternak juga akan menurun karena jumlah bibit ayam yang di pelihara oleh peternak akan menjadi berkurang (Kasus et al., 2017)

\section{Pengaruh Bibit Terhadap laba usaha peternak ayam broiler}

Bibit yang unggul akan memperbaiki kualitas perkembangan ayam yang akan di perlihara, hasilnya yang meningkat tentu akan menambah laba peternak ayam jika ayam bagus berkembang secara maksimal (Ponaryo, 2017).

\section{Pengaruh pakan Terhadap laba usaha peternak ayam broiler}

Pakan ayam tergantung kepada pemberian pakan ayam nya, dimana pemberian pakan yang berlebihan akan mengurangi keuntungan usaha ayam broiler (Magetan, 2016).

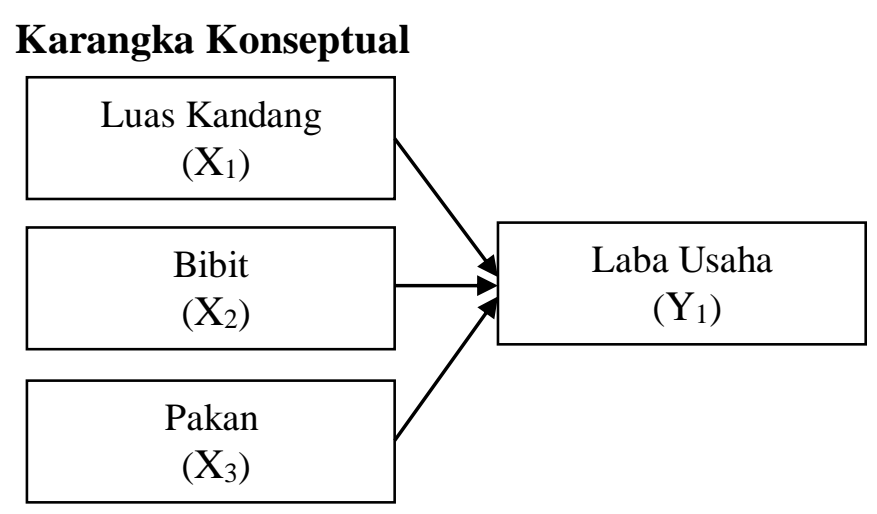

Gambar 1

\section{Kerangka Konseptual}

Dari gambar 1 di atas, penelitian ini akan melihat pengaruh dari pada luas lahan $\left(\mathrm{X}_{1}\right)$, bibit $\left(\mathrm{X}_{2}\right)$ dan pakan $\left(\mathrm{X}_{3}\right)$ terhadap laba usaha $(\mathrm{Y})$. Selanjutnya luas lahan, bibit dan pakan akan dilihat pengaruhnya ke arah laba usaha.

\section{Hipotesis}

Agar penelitian ini lebih terarah, maka penulis mencoba membuat suatu dugaan sementara tentang hasil penelitian ini yang penulis 
rangkum dalam sebuah hipotesis. Dari latar belakang penelitian dan tinjauan teoritis yang telah dikemukakan maka yang menjadi hipotesis dalam penelitian ini adalah:

$\mathrm{H}_{1}$ : Diduga luas kandang berpengaruh secara positif dan siqnifikan terhadap laba usaha.

$\mathrm{H}_{2}$ : Diduga bibit berpengaruh secara positif dan siqnifikan terhadap laba usaha.

$\mathrm{H}_{3}$ : Diduga pakan berpengaruh secara positif dan siqnifikan terhadap laba usaha.

\section{METODE PENELITIAN}

\section{Populasi dan Sampel}

Populasi adalah jumlah kesuluruhan dari unit atau objek analisa yang ciri-ciri karakteristiknya hendak diduga (Sugiyono, 2006). Jumlah populasi peternak 155 (kecamatan).

Sampel merupakan unit-unit yang memiliki populasi secara kesuluruhan (Sugiyono, 2006). Sampel merupakan bagian dari populasi yang diambil melalui cara-cara tertentu yang juga memiliki karakteristik tertentu jelas dan lengkap yang dianggap bisa mewakili populasi. Menurut (Boediono, 2004) sampel merupakan bagian karakteristik atau orang-orang dari suatu populasi menjadi objek penelitian.

Metode Sampling yang digunakan dalam penelitian ini adalah non probability sampling dengan teknik sampling purposive. Non probability sampling merupakan pengambilan sampel dilakukan secara subjektif oleh peneliti, akibat adanya penilaian tertentu oleh peneliti terhadap elemen, dan dapat juga diakibatkan oleh keadaan yang memaksa peneliti untuk mengambil suatu sampel tertentu. Sampling Purposive adalah teknik penentuan sampel dengan pertimbangan tertentu. Misalnya akan melakukan penelitian tentang kualitas makanan, maka sampel sumber datanya adalah orang yang ahli makanan, atau penelitian tentang kondisi politik di suatu daerah, maka sampel sumber datanya adalah orang yang ahli politik (Sugiyono, 2006). Teknik pengambilan sampel dalam penelitian ini menggunakan metode sampel Purposive Sampling yaitu Sampling yang dilakukan berdasarkan keputusan peneliti, Bentuk pengambilan sampel ini berdasarkan kebetulan, yaitu siapa saja yang kebetulan bertemu dengan peneliti ini dan dianggap cocok menjadi sumber data akan menjadi sampel penelitian ini yaitu.

$$
\mathrm{n}=\quad \frac{\mathrm{N}}{1+\mathrm{N}(\mathrm{e})^{2}}
$$

Dimana:

$\mathrm{N}$ = Jumlahpopulasi

$\mathrm{n}=$ Jumlahsampel

$\mathrm{e}=$ Batas nilai kesalahan pengambilan sampel sebesar $10 \%$

$$
\begin{aligned}
n & =\frac{155}{1+155(0,1)^{2}} \\
& =60,78 \text { Dapat dibulatkan menjadi } 61
\end{aligned}
$$

Sehingga sampel dalam penelitian ini berjumlah 61 orang. Sampel yang digunakan dalam penelitian ini dipilih menggunakan purposive sampling, karena pada umumnya tepat digunakan pada penelitian-penelitian yang memeiliki ukuran sampel relative kecil. Menurut (Slovin, 2005)

\section{Definisi Operasional Variabel}

Definisi operasional merupakan petunjuk bagaimana variabel-variabel dalam penelitian diukur. Untuk memperjelas dan mempermudah pemahaman terhadap variabel-variabel yang akan dianalisis dalam penelitian ini, maka perlu dirumuskan definisi operasional yaitu sebagai berikut:

1. Laba Usaha (Y) adalah penerimaan yang diperoleh untuk setiap kali panen yang dinyatakan dalam Rupiah.

2. Luas kandang $\left(\mathrm{X}_{1}\right)$ adalah luas area yang digunakan peternak ayam broiler untuk beternak yang dinyatakan dalam $\mathrm{m}^{2}$ (meter kuadrat).

3. Bibit ayam $\left(\mathrm{X}_{2}\right)$ adalah jumlah bibit ayam yang dipelihara peternak di awal usaha dinyatakan dalam ekor.

4. Pakan $\left(\mathrm{X}_{3}\right)$ adalah biaya pakan dari awal usaha sampai panen yang dinyatakan dalam Rupiah. 


\section{Metode Analisis Data}

Untuk membahas permasalahan dan membuktikan hipotesis yang telah dikemukaan, metode analisis yang dipakai dalam penelitian ini digunakan model regresi linier berganda dengan bantuan program EViews-9 adapun formulasi model regresi linier berganda dalam penelitian ini adalah sebagai berikut:

$Y=\beta_{0}+\beta_{1} X_{1}+\beta_{2} X_{2}+\beta_{3} X_{3}+e$

Dimana :

$\begin{array}{ll}\mathrm{Y} & =\text { Laba Usaha } \\ \beta_{0} & =\text { Konstanta } \\ \beta_{1}, \beta_{2}, \beta_{3} & =\text { Koefisien Regresi Variabel } \\ \mathrm{X}_{1} & =\text { Luas Kandang } \\ \mathrm{X}_{2} & =\text { Bibit } \\ \mathrm{X}_{3} & =\text { Pakan } \\ \mathrm{e} & =\text { Error term (Variabel }\end{array}$

Pengganggu)

\section{HASIL PENELITIAN DAN PEMBAHASAN}

\section{Hasil Penelitian}

Gambaran Umum lokasi Penelitian

Kecamatan Bangun Purba adalah Kecamatan hasil pemekaran dari Kecamatan Rambah Kabupaten Rokan Hulu dengan luas wilayah $\pm 17.190 \mathrm{Ha}$ dan topografinya yang berbukit dan bergelombang, DPAL \pm 80 Mterdiri dari Hutan: $\quad 35 \%$, Lahan Perkebunan: 30\%Pertanian: 20\% Perkantoran dan Perumahan: 15\% Kecamatan Bangun Purba memiliki jumlah Penduduk sebanyak \pm 15.199 jiwa, dengan jumlah Kepala Keluarga (KK) sebanyak 3.880.

\section{Batas batas kecamatan Bangun Purba}

Dilihat dari bentang wilayah Kecamatan Bangun Purba memiliki batas wilayah dengan :
* Sebelah Utara Dengan Kecamatan Tambusai/Rambah Hilir.
* Sebelah Timur Dengan Kecamatan Rambah.
* Sebelah Selatan Dengan Kecamatan Rambah/Prov. Sumbar.
* Sebelah Barat Dengan Prov. Sumatera Utara.

\section{Demografi}

Kabupaten Deli Serdang banyak memiliki Keanekaragaman budaya, yang disamakan oleh semua suku-suku yang ada di nusantara, Deli Serdang memiliki suku asli antara lain suku Melayu, suku karo, suku simalungun, serta ada suku pendatang yang dominan antara lain suku jawa, batak, minang, banjar dan lain-lain.

\section{Hasil Analisis Regresi Linear Berganda}

Hasil uji regresi ini bertujuan untuk mengetahui bagaimana pengaruh variabel-variabel independen terhadap variabel dependen.Untuk mengetahui hasil penelitian ini dapat dilihat dari output regresi linear berganda yang memakai program EVIEWS sebagai alat analisis pada penelitian ini pada keterangan Tabel 2 berikut ini:

\section{Tabel 2}

\section{Hasil Analisis Regresi Linier Berganda}

Dependent Variable: $Y$

Method: Least Squares

Date: 07/26/18 Time: 09:33

Sample: 161

Included observations: 61

\begin{tabular}{lrlrr}
\hline \hline \multicolumn{1}{c}{ Variable } & Coefficient & Std. Error & t-Statistic & Prob. \\
\hline C & 46857501 & 2061643. & 22.72823 & 0.0000 \\
X1 & -4640.841 & 2124.303 & -2.184642 & 0.0330 \\
X2 & 3256.817 & 542.4688 & 6.003694 & 0.0000 \\
X3 & -0.156714 & 0.032716 & -4.790077 & 0.0000 \\
\hline \hline R-squared & 0.428040 & Mean dependent var & 43719057 \\
Adjusted R- & & & & \\
squared & 0.397937 & S.D. dependent var & 1466145. \\
S.E. of regression & 1137622. & Akaike info criterion & 30.79010 \\
Sum squared resid & $7.38 E+13$ & Schwarz criterion & 30.92852 \\
Log likelihood & -935.0981 & Hannan-Quinn criter. & 30.84435 \\
F-statistic & 14.21913 & Durbin-Watson stat & 2.228342 \\
Prob(F-statistic) & 0.000000 & & \\
\hline \hline
\end{tabular}

\section{Sumber data diolah 2018}

Dari Tabel 2 diatas maka model regresi adalah sebagai berikut:

$$
Y=46857501-4640.841 X 1+3256.817 X 2-
$$

\section{$0.156714 X 3$}

Dari Formulasi model diatas menunjukan bahwa

1. Nilai variabel konstanta dari variabel dependen memiliki nilai sebesar 46857501 yang berarti bahwa jika variabel observasi luas, bibit dan 
biaya pakan dianggap tidak adamaka nilai variabel dependen laba usaha peternak memiliki nilai konstan sebesar Rp 46857501

2. Koefisien dari variabel x1 mempunyai Nilai negatif yaitu -4640.841 yang berarti apabila luas meningkat $1 \mathrm{~m}^{2}$ Maka akan menurunkan laba sebesar Rp 4.640,841

3. Nilai koefisien dari variabel $\mathrm{x} 2$ mempunyai nilai positif yaitu sebesar 3256.817yang berarti apabila bibit yang di gunakan meningkat senilai 1 ekor maka jumlah laba usaha peternak akan meningkat sebesarRp 3.256,817

4. Nilai koefisien dari variabel $\mathrm{x} 3$ mempunyai nilai Negatif yaitu sebesar -0.156714yang berarti apabila pakan yang di gunakan meningkat 1 rupiah maka jumlah laba usaha peternak akan menurun sebesar Rp 0.156714.

\section{Uji Asumsi Klasik}

\section{Uji Multikolinearitas}

Uji Multikolinieritas bertujuan untuk menguji apakah model regresi ditemukan adanya korelasi antar variabel bebas atau dependent, (Boediono, 2004)Untuk menguji hipotesis ini digunakan perhitungan dengan program komputans EVIEWS 9.

\section{Tabel 3}

\section{Hasil Uji Multikolinieritas}

Variance Inflation Factors

Date: 07/26/18 Time: 11:13

Sample: 161

Included observations: 61

\begin{tabular}{cccc}
\hline \hline Variable & $\begin{array}{c}\text { Coefficient } \\
\text { Variance }\end{array}$ & $\begin{array}{c}\text { Uncentered } \\
\text { VIF }\end{array}$ & $\begin{array}{c}\text { Centered } \\
\text { VIF }\end{array}$ \\
\hline \hline C & $4.25 E+12$ & 200.3370 & NA \\
X1 & 4512662. & 261.4638 & 1.790599 \\
X2 & 294272.4 & 684.2743 & 4.314515 \\
X3 & 0.001070 & 894.8862 & 4.968214 \\
\hline \hline
\end{tabular}

Sumber: Hasil Eviews, Data Di Olah (2018)

Berdasarkan Tabel 3 di atas dapat dikatakan bahwa model ini terbebas dari permasalah multikoloniearitas dengan melihat hasil output antara variabel pada tabel kolom centered VIF. nilsi VIF untuk fariabel luas
1.790599

BIBIT 4.314515

dan

PAKAN 4.9668214 di karenakan nilai VIF dari ketiga variabel nilainya tidak ada yang melebihi atau lebih besar dari 10 maka dapat dikatakan dalam penelitian ini tidak terjadi permasalahan multikolenieritas pada ketiga variabel bebas yang di teliti

\section{Uji Heteroskedastisitas}

(Ghozali, 2007)menyatakan bahwa pengujian heteroskedasitas bertujuan untuk mengetahui apakah didalam modal regresi terjadi ketidaksamaan varian dan residual satu pengamatan dengan pengamatan lainnya. Jika varian dan residual satu pengamatan ke pengamatan lain tetap maka disebut homokedasitas, jika berbeda disebut heteroskedasitas.

\section{Tabel 4}

\section{Hasil Uji HeterosKedastisitas}

Heteroskedasticity Test: White

\begin{tabular}{llll}
\hline \hline F-statistic & 0.802342 & Prob. F(9,51) & 0.6159 \\
Obs*R-squared & 7.565744 & Prob. Chi-Square(9) & 0.5784 \\
Scaled explained & & & \\
SS & 7.384906 & Prob. Chi-Square(9) & 0.5971 \\
\hline \hline
\end{tabular}

Sumber : Hasil Penelitian (Output Eviews), 2018

Berdasarkan Tabel 4 nilai Probalitas Obs*R-squared sebesar $0.5784>$ alpha $(\alpha=0.05)$. Dapat disimpulkan bahwa hasil uji terbebas dari uji asumsi klasikheteroskedastisitas

\section{Uji Normalitas}

Ujinormalitas adalah untuk mengetahui apakah residual terdistribusi secara normal atau tidak. Pengujian normalitas dapat dilakukan dengan menggunakan metode Jarque-Bera (J-B) (Widarjono, 2008).

Jika nilai probality dari statistic J-B lebih besar dari taraf kepecayaan $5 \%(0,05)$ berarti bahwa residual data berdistribusi normal, sebaliknya jika nilai probability dari satistik J-B lebih kecil dari taraf kepercayaan $5 \%(0,05)$ berarti bahwa residual data tidak berdistribusi normal (Widarjono,2008) 


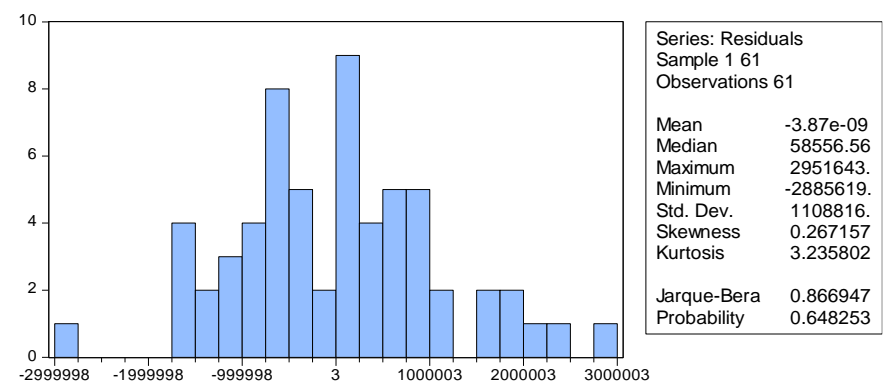

Sumber; Hasil Penelitian (Data Diolah :2018)

Gambar 2

Uji Normalitas Jarque Bere (J-B) Test

Berdasarkan gambar 2 di atas, hasil penelitian menemukan nlai Jarque-Bera Test adalah 0.866947dengan tingkat signifikan 0,64 atau lebih besar dari $0,05 \%$ atau $5 \%$ dengan demikian dapat di simpulakan bahwa data dalam penelitian ini terdistribusi normal. Yang berarti bahwa data yang digunakan sudah baik untuk diteliti.

\section{Hasil Pengujian Hipotesis}

Suatu variabel dapat di katakan mempunyai pengaruhnya secara parsial antara variabel independen terhadap variabel dependen terhadap variabel dependen apabila nilai dari $\mathrm{t}$ hitung $>\mathrm{t}$ tabel dengan tingkat signifikan di bawah 0,05 adapun nilai $t$ tabel dapat di peroleh melalui rumus N-K-1 yakni 61-3-1=57 dengan taraf signifikan $5 \%$ maka di temukan nilai t tabel sebesar yaitu nilai $\mathrm{t}$ statistik lebih besar dari nilai t tabel.

Sedangkan untuk mendapatakan nilai $f$ tabel dapat di lihat pada df $1=3$ dan df $1=57$ sehingga jumlah F tabel yaitu sebesar 1.67203 dengan asumsi bahwa nilai $\mathrm{F}$ satistik harus lebih besar nilainya dari f table

\section{Hasil Uji Parsial (Uji t)}

Pengaruh Luas kandang terhadap laba usaha peternak ayam broiler di kecamatan bangun purba

Dari Tabel di atas, menunjukan bahwa variabel luas kandang memiliki nilai thitung sebesar -2.184642 dengan nilai probabilitas statistiknya sebesar 0.0365 , denga nilai ttabel dengan (Df) $=\mathrm{n}-\mathrm{k}(61-4=57)$ pada $\alpha=5 \%$. maka dapat disimpulkan bahwa thitung >ttabel, yaitu 2.184642>1.672. dengan nilai signifikan 0.0330, maka keputusanya yaitu luas kendang berpengaruh tidak signifikan terhadap laba usaha maka $\mathrm{H} 1$ di terima dan tolak h0.

\section{Pengaruh bibit terhadap laba usaha peternak ayam broiler di kecamatan bangun purba}

Berdasarkan Tabel di atas, dapat dilihat bahwa dari variabel biaya pupuk memilki nilai thitung> t-tabel yaitu 6.003694>1.67203 dengan nilai signifikannya adalah $0,0000<5 \%(0,05)$. Keputusan menerima $\mathrm{H} 2$.

\section{Pengaruh pakan terhadap laba usaha peternak ayam broiler di kecamatan bangun purba}

Berdasarkan Tabel di atas, dapat dilihat bahwa dari variabel biaya pestisida memilki nilai thitung> ttabelyaitu -4.790077>1.67203 dengan nilai signifikan atau probabilitasnya adalah $0.0000<5 \%(0,05)$.

\section{Hasil Uji Simultan}

Berdasarkan Tabel di atas apabila nilai $\mathrm{F}$ hitung > Ftabel Dan probabilitas, Yakni F hitung 14.21913>2.77dengan tingkat kesalahan error $\alpha$ (alpha) 0,05 yang telah di tentukan maka dapat dikatakan bahwa model regresi yang telah di estimasikan adalah layak. Sehingga dapat disimpulkan bahwa model regresi yang di estimasikan layak di gunakanuntukmenjelaskan factor-faktor yang mempengaruhi laba usaha peternak ayam broiler di kecamatan bangun purba

\section{Hasil Uji Koefisien Korelasi (R)}

Untuk mengetahui pengaruh dari variabel luas lahan terhadap peningkatan pendapatan petani padi sawah dikecamatan meurah mulia kabupaten aceh utara dapat di lihat dari nilai $\mathrm{R}$ atau $\sqrt{\mathrm{R}^{2}}=$ $\sqrt{ } 0.428040=0,654247659529631$ atau $65 \%$, maka angka ini menunjukan bahwa anatara luas kandnag, bibit, pakan dan laba usaha peternak ayam broiler di kecamatan bangun purba memiliki hubungan yang sangat kuat atau memiliki korelasi yang sangat kuat. 


\section{Hasil Uji Koefisien Determinasi $\left(\mathbf{R}^{\mathbf{2}}\right)$}

Uji koefisien determinasi digunakan untuk mengukur seberapa jauh kemampuan dari model regresi dalam menjelaskan variabel-variabel terikat, maka jika di lihat dari nilai $\mathrm{R}^{2}$ atau nilai koefisien determinasi, pada tabel 4.8 dapat di lihat dari Adjusted R-Squared diperoleh nilai $\mathrm{R}^{2}$ sebesar 0.397937 yang berarti kemampuan variabel Luas kendang,bibit dan pakanmenjelaskan tidak pengaruhnya terhadap laba usaha peternakan ayam sebesar39\%dansisanya sebesar61\% di penaruhi oleh faktor atau Variabel lain

\section{Pembahasan}

Penelitian penulis menyimpulkan bahwa bibit secara parsial berpengaruh signifikan terhadap laba usaha peternakan ayam broiler di kecamatan bangun purba kabupaten deli serdang.ini sesuai dengan yang di lakukan penelitian (Umam, 2017) melakukan penelitian dengan judul "Analisis Efisensi produksi Usaha peternakan ayam ras pedaging pola kemitraan dan mandiri di kota palu provinsi Sulawesi tengah"

\section{KESIMPULAN DAN SARAN}

\section{Kesimpulan}

Berdasarkan hasil penelitian dan pembahasan di atas, maka penulis mengemukaan kasimpulan sebagai berikut:

1. Berdasarkan hasil pengujian yang telahdi lakukan secara parsial maka hasil bibit berpengaruh terhadap laba usaha peternak ayam broiler di Kecamatan Bangun Purba Kabupaten Deli Serdang

2. Berdasarkan hasil pengujian yang telah dilakukan secara parsial dengan menggunakan uji $\mathrm{t}$ dapat disimpulkan bahwa secara individual (parsial) antara variabel independen bibitberpengaruh signifikan terhadap variabel dependen laba usaha peternak ayam broiler di Kecamatan Bangun Purba Kabupaten Deli Serdang.

3. Dari hasil pengujian regresi maka dapat di simpulkan hasil dari Adjustik R-square sebesar $39 \%$ yang berarti kemampuan variabel luas kandang, bibit dan pakan menjelaskan pengaruhnya terhadap laba usaha peternak ayam broiler sebesar 39\% dan sisanya sebesar $61 \%$ di penaruhi oleh faktor atau variabel lain.

\section{Saran}

Berdasarkan hasil olah data, hasil pembahasan dan kesimpulan di atas, maka penulis dapat merekomendasikan beberapa saran, diantaranya sebagai berikut:

1. Pemerintah, khususnya Dinas perternakan di harapkan dapat lebih meningkatkan sosialisasi atau penyuluhan mengenai penggunaan bibit dan pakan sesuai dengan luas kandan berguna menambah wawasan petani yang pada akhirnya di harapkan mampu mendapatkan hasil yang maksimal (Pendapatan).

2. Di harapakan para peternak kecamatan bangun purba kabupaten deliserdang dapatmenerima saran daridinasterkait agar hasil laba menjadi lebih baik lagi.

3. Untuk peneliti selanjutnya penelitian ini di harapkan dapat menjadi bahan evaluasi atau perbandingan agar hasil atau pengaruhnya menjadi lebih baik dan lebih besar terhadap laba usaha peternak ayam broiler misalny asaja jam kerja atau jumlah tenaga kerja.

\section{DAFTAR PUSTAKA}

Dharmawan, R., Prayogi, H. S., \& Nurgiartiningsih, V. M. A. (2005). Penampilan produksi ayam pedaging yang dipelihara pada lantai atas dan lantai bawah, 26(3), 27-37.

Ghozali. (2007). Penelitian Kuantitatif. 6-10.

Jamaika, P., Ilmu, J., Dan, E., Pembangunan, S., Ekonomi, F., \& Jember, U. (2014). Analisis faktor yang mempengaruhi pendapatan pengusaha mebel di kecamatan leces kabupaten probolinggo.

Kasus, S., Pete (2017). ANALISIS USAHA PETERNAKAN AYAM RAS PEDAGING ( BROILER ) DENGAN POLA KEMITRAAN, 1-10.

Magetan, N. K. (2016). faktor-faktor yang mempengruhi laba usaha peternakan ayam broiler di kabupaten bandung, 18(1).3-10

Osburn (2017). Analisis Pendapatan Peternak 
Mitra Terhadap Pelaksanaan Kemitraan Ayam Broiler (Kasus Kemitraan PT. Cemerlang Unggas Lestari, Semarang), 3(1).

Ponaryo (2017). Faktor-faktor yang mempengaruhi pendapatan wanita pada usaha lemang dan kontribusinya pada pendapatan keluarga di kota tebing tinggi, 1-15.

Rachmawati, (2017). Meningkatkan produksi ayam pedaging melalui pengaturan proporsi sekam, pasir dan kapur sebagai litter., 38-45.

Sugiyono. (2006). uji asumsi klasik. 4-10.

Umam, (2015). THE PERFORMANCE OF BROILER REARING IN SYSTEM STAGE FLOOR AND, 24(3), 79-87.

Usahatani, (2015). Analisis Faktor-Faktor Yang Mempengaruhi Pendapatan Usahatani Pinang Kecamatan Sawang Kabupaten Aceh Utara, (1), 61-65.

Widarjono. (2008). uji asumsi klasik. 3-10. 